caused. However, raising the spectre of a mass murderer in relation to Canada's system of medical self regulation is inaccurate and unduly alarmist.

\author{
Albert J. Schumacher \\ CMA President \\ Ottawa, Ont. \\ References \\ 1. Can physicians regulate themselves? [editorial]. \\ CMA7 2005;172(6):717. \\ 2. Wright J. So, whom do we trust? Ipsos-Reid; Jan \\ 22, 2003. Available: www.ipsos-reid.com. \\ DOI:10.1503/cmaj.050358
}

\section{Gagner la confiance de nos patients}

$\mathrm{D}$ ans un éditorial récent du $\mathcal{F} A M C^{1}$, on utilise Harold Shipman, médecin de famille britannique et tueur en série notoire, comme exemple des «méfaits professionnels» causés par des médecins qui ont eu pour effet de miner la confiance du public envers la profession. Je ne saurais insister suffisamment moi-même sur le fait que la confiance de la population envers les médecins constitue la pierre angulaire de la relation médecin-patient, mais je conteste néanmoins votre affirmation selon laquelle la «confiance dans les médecins est à la baisse».

Les médecins du Canada sont toujours décrits comme étant très dignes de confiance ${ }^{2}$ dans les sondages conçus pour mesurer la confiance que le public accorde à diverses professions. Être identifié à l'une des professions les plus dignes de confiance, en même temps que les infirmières et les pharmaciens, ce n'est pas un honneur que l'on accorde ou reçoit à la légère.

Les organismes canadiens de représentation et de réglementation ont affirmé qu'il faut maintenir les normes la compétence des médecins et l'acquisition continue du savoir. Le plus important, peut-être, c'est qu'une nouvelle ère d'ouverture et de transparence s'est ouverte avec la représentation accrue du public aux conseils de régie des collèges des médecins et chirurgiens et la publication de rapports périodiques, accessibles au public, sur les sanctions disciplinaires et les enquêtes.

L'affaire Shipman représente un épisode tragique de l'histoire de la médecine et comme médecins, l'horreur et la douleur causées par cette personne nous répugnent à tous. Évoquer le spectre de l'auteur d'une série de meurtres à l'égard du système d'autoréglementation de les plus rigoureuses possibles d'éthique,

la médecine au Canada, c'est cependant à la fois erroné et indûment alarmiste.

\section{Albert J. Schumacher \\ Président, l'AMC \\ Ottawa (Ont.)}

\section{Références}

1. Les médecins sont-ils capables de s'autoréglementer? [éditorial]. FAMC 2005;172(6):719.

2. Wright J. So, whom do we trust? Ipsos-Reid; 22 janvier 2003. Disponible à : www.ipsos-reid.com.

DOI:10.1503/cmaj.050359

\section{Corrections}

Tn a recent News item, ${ }^{1}$ the sentence "Studies have shown that patients initially lose between $35 \%-60 \%$ of baseline body weight and maintain weight reductions of approximately $16 \%$ after 8 years" should have read "Studies have shown ... after 10 years."

\section{Reference}

1. Padwal RS, Lewanczuk RZ. Trends in bariatric surgery in Canada, 1993-2003. CMA7 2005;172 (6): 735 .

DOI:10.1503/cmaj.050360

$\mathrm{T}$ he following DOI was mistakenly omitted from a recent item ${ }^{1}$ in the Analysis section of the journal: DOI:10.1503/cmaj.050370.

\section{Reference}

1. Secko D. Targeting hard-to-treat cancers. CMA7 2005;172(8):993.

\section{Letters submission process}

CMAJ's enhanced eletters feature is now the portal for all submissions to our letters column. To prepare an eLetter, visit www.cmaj.ca and click "Submit a response to this article" in the box near the top right-hand corner of any eCMAJ article. All eLetters will be considered for publication in the print journal.

Letters written in response to an article published in CMAJ are more likely to be accepted for print publication if they are submitted within 2 months of the article's publication date. Letters accepted for print publication are edited for length (usually 250 words) and house style.
DOI:10.1503/cmaj.050374

$I^{n}$ a recent research paper, ${ }^{1}$ the corresponding author's email address should have read jasoon@interchange .ubc.ca.

\section{Reference}

1. Soon JA, Levine M, Osmond BL, Ensom MHH, Fielding DW. Effects of making emergency contraception available without a physician's prescription: a population-based study. CMAJ 2005;172(7):878-83.

DOI:10.1503/cmaj.050384 